Division of Geological \& Geophysical Surveys

RAW-DATA FILE 2015-14

JUMBO DOME, INTERIOR ALASKA:

WHOLE-ROCK MAJOR- AND TRACE-ELEMENT ANALYSES

by

C.E. Cameron, C.J. Nye, K.F. Bull, and Rebecca-Ellen Woods

$\$ 2.00$

SEPTEMBER 2015

THIS REPORT HAS NOT BEEN REVIEWED FOR TECHNICAL CONTENT OR FOR CONFORMITY TO THE EDITORIAL STANDARDS OF DGGS

\author{
Released by \\ STATE OF ALASKA \\ DEPARTMENT OF NATURAL RESOURCES \\ Division of Geological \& Geophysical Surveys \\ 3354 College Road \\ Fairbanks, Alaska 99709-3707
}

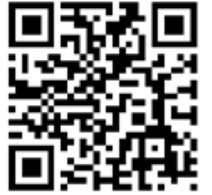





\title{
JUMBO DOME, INTERIOR ALASKA: WHOLE-ROCK MAJOR- AND TRACE-ELEMENT ANALYSES
}

by

\author{
C.E. Cameron ${ }^{1}$, C.J. Nye ${ }^{1}$, K.F. Bull ${ }^{2}$, and Rebecca-Ellen Woods ${ }^{3}$ \\ ${ }^{1}$ Alaska Division of Geological \& Geophysical Surveys \\ ${ }^{2}$ Geological Survey of New South Wales \\ ${ }^{3}$ Shannon and Wilson, Inc.
}

\section{Introduction:}

Jumbo Dome is a hornblende andesite dome of Pleistocene age located in the Healy Quadrangle of central Alaska, about $19 \mathrm{~km}$ northeast of Healy (Albanese, 1980; Athey and others, 2006) (fig. 1, 2, 3). Jumbo Dome is approximately $1.6 \mathrm{~km}$ long, $1.3 \mathrm{~km}$ wide, and $500 \mathrm{~m}$ high and intrudes the Devonian Keevy Peak Formation basement (slate, quartz-sericite schist, graphitic schist, calcareous schist, quartz-feldspar metawacke, and conglomerate) and overlying Tertiary Suntrana Formation (sandstone, clay, and coal) (Albanese, 1980; Wahrhaftig and others, 1969). A single ${ }^{40} \mathrm{Ar} /{ }^{39} \mathrm{Ar}$ date of a sample from Jumbo Dome yielded a plateau age of $1.026 \pm 0.057$ Ma (Athey and others, 2006).

Jumbo Dome is not well studied and these samples plus the three analyses from Albanese (1980) represent the known total of published whole-rock geochemical analyses for this volcanic feature. Jumbo Dome lava has the diagnostic arc signature of low ratios of concentrations of high-field-strength elements to large-ion-lithophile elements (for example, $\mathrm{Nb} / \mathrm{La}, \mathrm{Nb} / \mathrm{Rb}$ ).

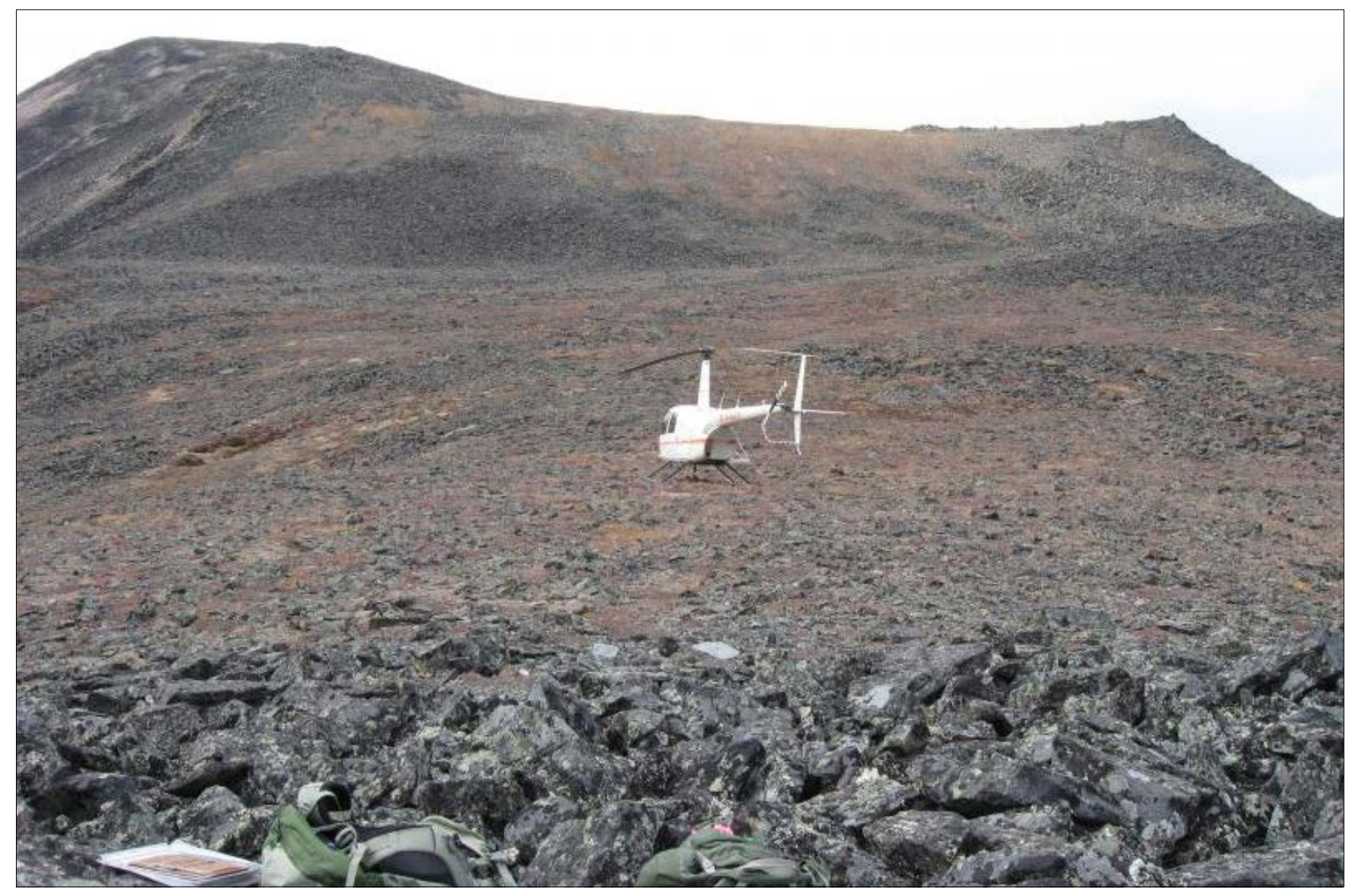

Figure 1. Looking northwest at summit of Jumbo Dome. Photo by Cheryl Cameron, 2011. 


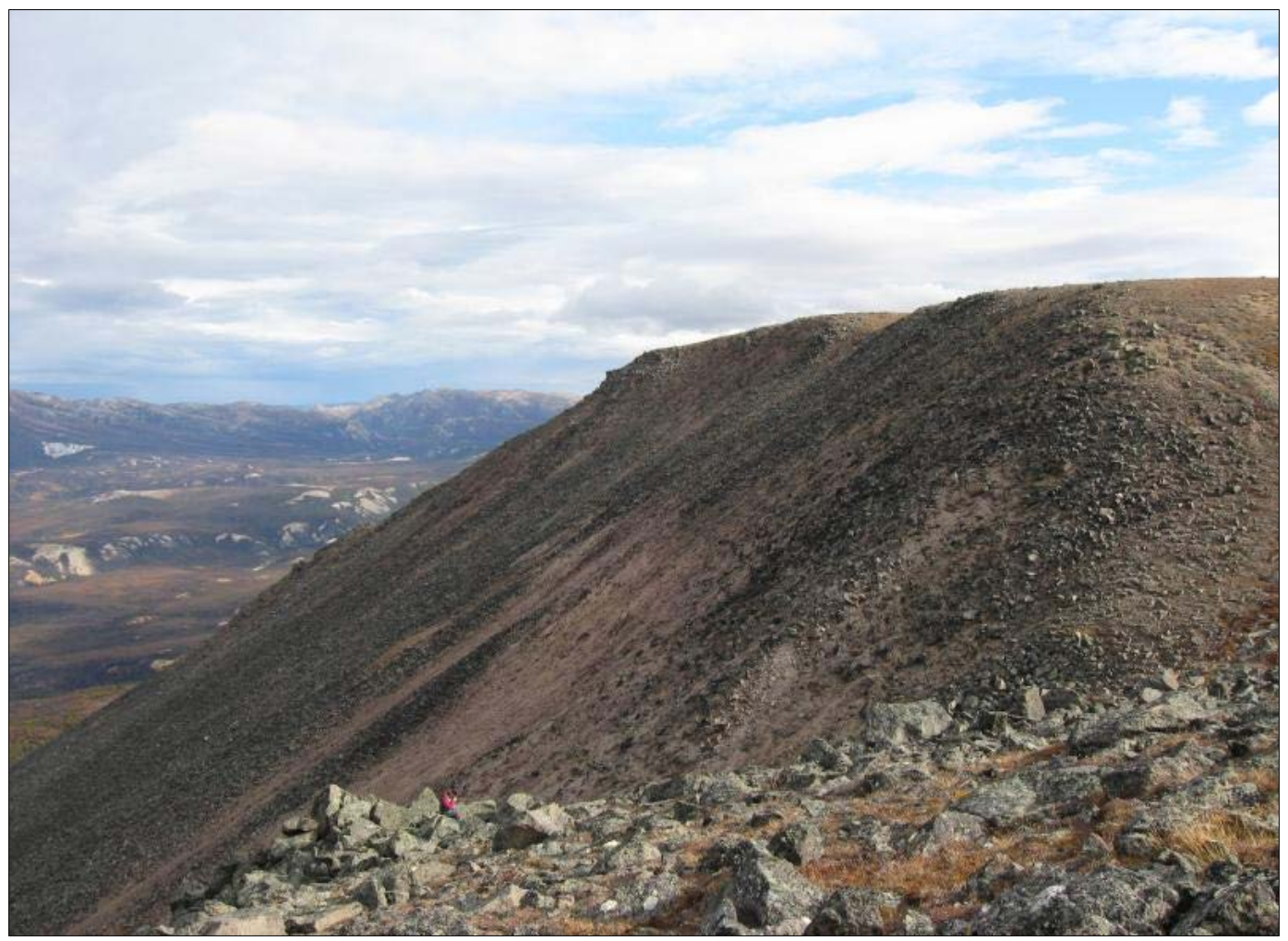

Figure 2. DGGS geologist Katharine Bull examines rocks just downhill of station 11JDKFB003 on Jumbo Dome. Photo by Cheryl Cameron, 2011.

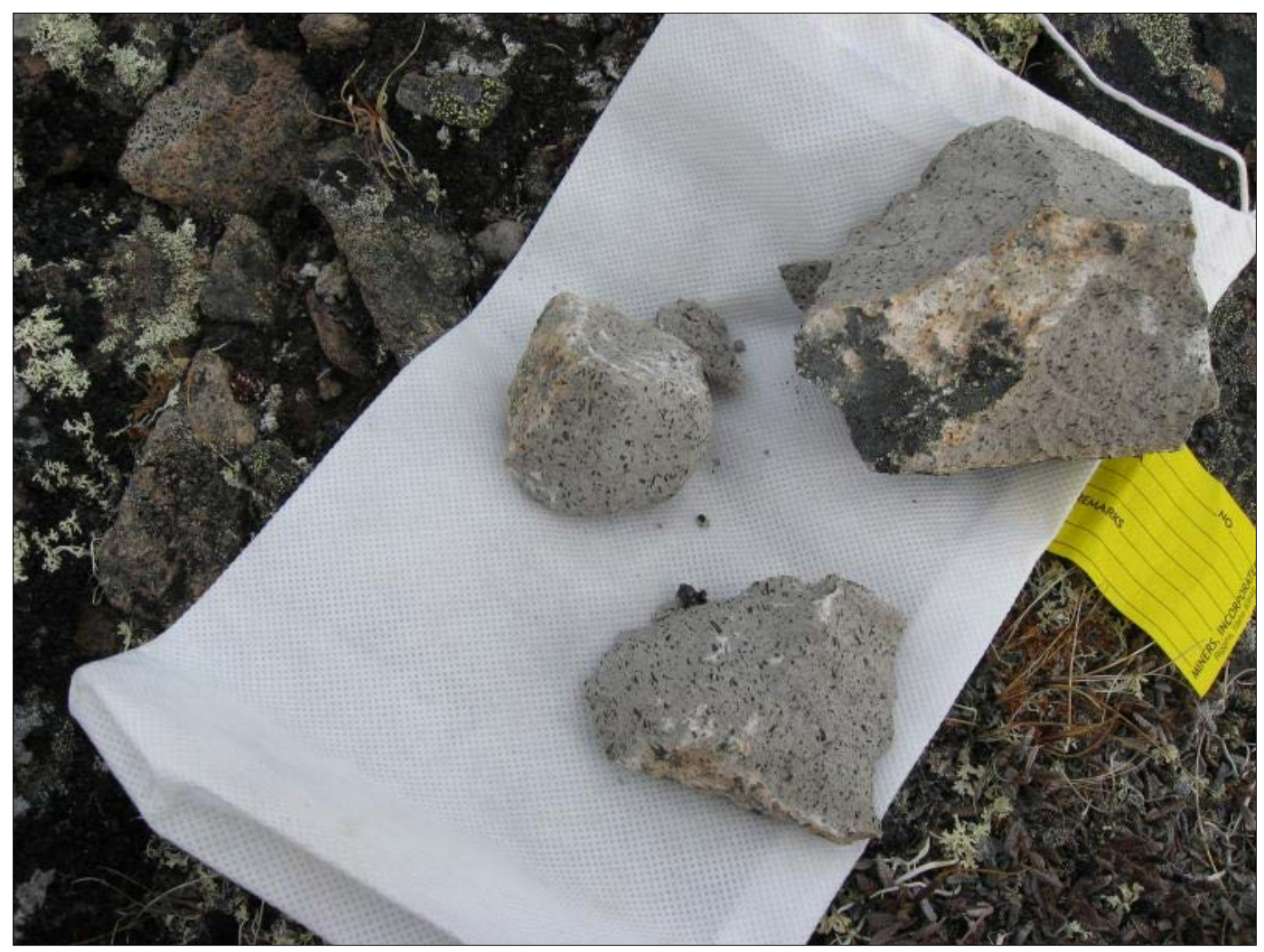

Figure 3. Sample 11JDCEC001b, of gray hornblende andesite from Jumbo Dome. Andesite is pyroxene bearing, slightly vesicular, and often very weathered/altered. This sample bag is 5 inches wide at its shortest dimension. Photo by Cheryl Cameron, 2011. 


\section{Documentation of methods:}

Rock samples from two separate trips to Jumbo Dome (2005 and 2011) were analyzed for major and trace elements by $x$-ray fluorescence (XRF) and inductively coupled plasma-mass spectrometry (ICPMS) at Washington State University's Geoanalytical Laboratory in Pullman, WA. Sample descriptions and locations are provided in the accompanying tables. Location data were collected with handheld GPS. Latitude and longitude are reported in the WGS84 datum. XRF and ICPMS analyses were performed following the methods of Johnson and others (1999) and Knaack and others (written commun., 1994). Whole-rock oxides are normalized to 100 percent; all iron is reported as FeO. All intensity values were reduced using a single calibration file to decrease interbatch analytical variations. The precision of the results is dependent on both value measured and analyte; data shown here are as provided by the analytical lab; not all figures may be significant.

Accompanying tables also include whole-rock data from Albanese (1980). These samples were analyzed by XRF at University of Oregon, Eugene, OR. Originating work did not specify location coordinates or provide detailed sample information.

\section{References:}

Albanese, Mary, 1980, The geology of three extrusive bodies in the central Alaska Range: Fairbanks, University of Alaska Fairbanks, unpublished M.S. thesis, 104 p.

Athey, J.E., Newberry, R.J., Werdon, M.B., Freeman, L.K., Smith, R.L., and Szumigala, D.J., 2006, Bedrock geologic map of the Liberty Bell area, Fairbanks A-4 Quadrangle, Bonnifield mining district, Alaska: Alaska Division of Geological \& Geophysical Surveys Report of Investigation 2006-2 v. 1.0.1, 98 p., 1 sheet, scale 1:50,000. doi: $\underline{10.14509 / 15026}$

Johnson, D.M., Hooper, P.R., and Conrey, R.M., 1999, XRF analysis of rocks and minerals for major and trace elements on a single low-dilution Li-tetraborate fused bead: Advances in X-ray Analysis, v. 41, p. 843-867.

Wahrhaftig, Clyde, Wolfe, J.A., Leopold, E.B., and Lanphere, M.A., 1969, The coal-bearing group in the Nenana coal field, Alaska: U.S. Geological Survey Bulletin 1274-D, p. D1-D30. 